\title{
POLITICAL AWARENESS AMONG MADHESHI WOMEN OF PARSA DISTRICT: A CASE STUDY
}

\author{
Sushma Tiwari \\ Department of Population Studies, TU, Thakur Ram Multiple Campus, Birganj, Nepal \\ email: tiwarisushma@yahoo.com
}

\begin{abstract}
Since half of the population of Nepal consists of women, it is natural that they should claim their rightful place in the society. Women's political empowerment is a key component of democracy. Women's relative status, however, varies from one ethnic group to another. Madheshi women are known to be more socially, politically, and economically oppressed than their Nepali sisters of other ethnic backgrounds.

Ensuring participation at the grassroots level alone is not adequate for empowerment of women. Madheshi women have participated widely in political movements but after that they are relegated again to the domestic arena and drowned women's voices. So attaining positive role in national building, there should be identity, social inclusion, capacity enhancement which is the important prerequisites for a vibrant democracy and overall development of the country. This paper discussed on the situation of political awareness among Madheshi women of Parsa district. The primary data has used by the author in this research article.
\end{abstract}

\section{Keywords}

Political Awareness; Exclusion/Inclusion; Representation; Discrimination; Madhesh; Madheshi women

\section{Introduction}

Women's political participation and access to positions of power are two different issues. It has seen that number of women participate in political activities or in politics but very limited number of women have represented actively at decision making levels. When we talk about the situation and status of Madheshi women the picture is generally unsatisfactory.
They are more suppressed and backward than other sisters of other communities of Nepal. "Madheshi" literally refers to "the person who is suppressed". Deprived in different dimensions and degree, on which Madheshi are in the state of hard core exclusion. Madheshi are the non-hill origin people living in the- Madhesh (Terai) region. The Madheshi community is composed of the traditional hindu caste 
hierarchy such as Brahmin, Kshatriya, Baisya, and Dalits, and indinigenous Janjati ethnic groups, other native tribes and Muslims. In geographical terms, the Terai is the northern fringe southern slope of a northern extension of gangetic plane of the Indo-Gangetic plains abutting the foothills of the central Himalayas. It is a long and narrow strip of plains in the southern region of Nepal adjacent to the foothills of Siwalik or Churia Range.

The Madheshi community in spite of having long history of origin and habitat within the present day, Nepal is practically considered as outsiders and they have been mostly marginalized and faced exclusion in all the development sectors of life. Similarly this community exclusion from the national mainstream has been one of the negative factors hindering the sound economic development of this country. Socio-political and economic inclusion of Madhesh, generally considered as the 'bread basket' of the nation and the major source of revenue generation, including Madheshi people, is what the country requires for building a more inclusive nation based on democratic norms and processes.

The UN defines the status of women in the context of their access to knowledge, economic resources and political powers as well as their personal autonomy in the process of decision making, UN (1995). Ensuring political participation alone is not adequate for empowerment of women. Because women's participation and representation in decision making levels are two different issues. Madheshi women have participated widely in political movements but after that they are relegated again to the domestic arena and drowned women's voices.

Barban and Chaudhary (1994) have pointed that womenallovertheworld participatewidely in political movements in times of crisis, but one the crisis is over, they are relegated again to the domestic arena. This situation is true in Nepal. History shows that Nepalese women have very actively participated in the political movements, throughout the underground struggle and mass movement for democracy in 1990 and also during the Panchayat era. But once the multi-party system was restored the bargaining of various male dominated interest groups started to suppress women's voice and in taking ministerial positions, Acharya (1980). In the context of Nepal women's participation as voters have increases. Now women are aware of their own voting rights. Many women's organizations have been working in the area of women empowerment awareness programs among disadvantaged and deprived communities.

This research article also looks at the respondent's knowledge and perception and awareness of political activities among Madheshi women.

\section{Exclusion/inclusion of women in political participation in nepal}

Since half of the population of Nepal consists of women, it is natural that they should claim their rightful place in the society. Women's political empowerment is a key component of democracy. Women's relative status, however, varies from one ethnic group to another. Madheshi women are known to be more socially, politically, and economically oppressed than their Nepali sisters of other ethnic backgrounds. Meanwhile, they have been told since time immemorial that women's role is restricted to giving birth and feeding the family. Most of them they are kept within the four walls and even in one room, not allowed to talk with any other male members of family except her husband. She has to cover her face with her shawl in front of guests. She has to follow all the rules and regulation of the family and society and if she doesn't follow these rules, she has to suffer many kinds of violence and torture. Similarly, girl child is trained to carry out household jobs. Confidence and self-esteem are not cultivated during the socialization of a girl child. Gentleness, sacrifice, unassertiveness 
and often- feminine qualities are encouraged in a girl child. Decision making, ability of self - expression, opinion formulation and assertion of their needs and interest are mostly discouraged. Despite this a few Madheshi women have secured their positions in politics but still many of them have not secured a meaningful representation and recognition in the decision making level.

The Universal Declaration of Human Rights, 1948 affirms the equality of all persons regardless of the sex, colour, race, ethnicity, religion and Declaration of Discrimination against all forms of discrimination against women. Similarly CEDAW, 1995 reaffirms equality of women and their rights. Similarly, Article 33 (d) of the constitution of Nepal states to end discriminations based on class, ethnicity, lingual, gender, cultural, religion and region and to deconstruct the present centralized and unitary structure of the state to reconstruct it into an inclusive, democratic and forward looking one by addressing women, low caste (dalit), indigenous nationalities, Madheshi, oppressed, neglected, minority communities and backward regions, cited in Interim Constitution of Nepal (2007). Unfortunately, Madheshi women are still facing difficulties in achieving political positions. The issue of Madheshi women was neglected in the past but now many NGOs and civil societies concentrate in Madhesh and especially for the empowerment of Madheshi women.

The origin and proximity of Madheshi women to the power center also controls the access to the resource and hence the intensity and frequency of participation in the political process of the country. It is noted that the discriminatory rules to exclude Madheshi women from taking participation on state mechanism (for example the unfair quota system) has systematically allowed restricted participation in the governance of local and central level. It is one of the major social issues of Nepal based on the main themeSocial Exclusion/Inclusion. There is lack of district and regional level database concerned with female participation (Madheshi) in local governance as well as national level representation. While raising the issue of Madheshi women, it is the very recent practices in Nepal to analyze the issue through the lens of gender.

However, some barriers of inclusion are also present in Madheshi society. These are dowry system, untouchability, child marriage, child labours, Bokshi pratha, (Witch Belief). These forms of social evils still exist due to lack of awarness and high illiteracy in Madhesh, cited in Chaudhary Dipak (2008). Such types of barriers are the main causes of poor status of women in the governance as well as in the community.

According to the Human Development Report, the Madheshis are people who originated on Nepal's Plain, who lives in the Terai, and who feel marginalized by modern Nepali nationalism, which has rested on the ideas of monarchy, a single Nepali language, and a Hill-centric identity. This restrictive concept has excluded Madhessis- who speak varied language-among these Maithili, Awadhi, Bhojpuri, Urdu and Hindi-and who have extensive cultural, social and kinship links with Indian citizens living across the border in Bihar and Uttar Pradesh. These differences have led Hill Nepalies to view Madhesis with suspicion and to question their fitness for citizenship, UNDP (2009). Thus citizenship problem has also caused no name in voter list or not got opportunity to do vote and they lacked voting rights especially among illiterate and backward Madheshi women mostly due to patriarchal male dominant society.

Among Madheshi people the socio-economic condition of women is very vulnerable. No one NGOs/INGOs or government organizations have focused especially on Madheshi women's issues. Only addressing Madhesh issues can not solve all the problems of Madhesh because there are many women in Madheshi community have not got chance from any 
sector not only from government but from Madheshi community also. Women's poverty issues are different from men in the sense that it is not only associated with benefit of material resources or distributional justice but it is also associated with institutional norms and values visible and invisible of society. The common manifestations of women's poverty and gender inequality are rooted in the practices of gender roles, gender divisions of labour, power relations including lack of access to resources and benefits both in the private sectors (households/families) and public (outside of the households/families) spheres', see in HURDAC (2009).

According to the National living Standard Survey (NLSS), (2004), 31\% of total population of Nepal is below the poverty line and large disparity exists in poverty incidence across various geographical region and caste/ethnic group. In case of Terai, 34.5\% population is below the poverty line. Socio-cultural principle enriched with Hindu belief system, on which our social norms and practices are grounded, does not allow women to be heir of parental property and other dimensions are also not supportive for owning personal land or other highly valued property.

Majority of the women in politics have inherited the legacy of the political culture of the family and are bound to the responsibility arising from it. This applies to all women leader from the national level to the grassroots leaders. According to the report published by the election commission, in 19910.28 percent of the women were Village Development Committee Chairpersons, 0.45 percent VDC Vice Chair-persons and 0.58 percent of the women were Village Development Members. Similarly there were no any women, Mayor or Deputy Mayor and only 0.38 percent of the women were Municipality members, Women in Politics (1995). This figure clearly indicates that very few women have got chance to involve in local governance. This is also because of problems attached to the daily lives of women-child care, cooking, cleaning, etc, have been excluded from the political discourse.

Here inclusion refers to the equitable political representation of the excluded segments of Nepal's population, including women, various caste and ethnic groups, and those who live in underdeveloped regions. Participation implies the active engagement of representatives in voicing the views of their constituencies so that these opinions are heard and heeded. The Gender Empowerment Measure (GEM) indicates that it is 0.469 and Gender Development Index also indicates 0.482 in Terai region of Nepal which are lower than Hill region. However, Gender Empowerment Measure (GEM) has increased in all ecological regions due to quota systems of government; see Nepal Human Development Report, (2009).

Gender-based discrimination is rampant in Nepali society. It affects all women, whatever is their economic status, caste, ethnicity, or regional affiliation. A patriarchal worldview is embedded not only in social and cultural practices, but also in Nepal's systems of governance and its legal framework, permeating all aspects of the lives of women and girls, UNDP (2009). Gender discrimination is another barrier in the way of people's neither participation without which neither political awareness nor political participation is possible. Despite the constitutional guarantees for equal rights and opportunities to women, their participation in public life remains minimal, Shrestha and Hachhethu (2005). Despite this a few Madheshi women have secured their positions in politics but still many of them have not secured a meaningful representation and recognition in the decision making level. However, there are a certain segment of people who believe that political women are with a bad character. Arjen de Haan (1998) holds the opinions that social exclusion can be reflected through some recurrent factors. More prominently, policies and approaches of governmental programs and that of 
institutions to the people who are considered marginalized and disadvantaged is biased and also the state presence is almost negligible and that pushes to exclusion making people deprived in one way or other.

\section{Methods}

This research article is based on the primary data collection in 2011 and structured questionnaire were used to know political awareness among madheshi women. The respondents were randomly selected madheshi women aged 16-49 years. In this study Madheshi women were selected on the basis of their mother tongue (Bhojpuri, Maithali, Awadhi, Tharu) of Parsa district.

\section{Results and discussion}

Political expression for women, as defined by Giele and Smock (1977), is the right "to join in community decisions, to vote, to hold property or public offices on an equal basis with men."

The respondents were asked several questions in orders to gauge their political awareness, among them whether they were aware on their voting rights, their general knowledge on the name of their Constituent representative member of their own constituency. Table 1 presents the number of women whose name was listed in voter list.

Table 1: Percent distribution of women, whose name was in voter list

\begin{tabular}{|c|c|c|}
\hline $\begin{array}{l}\text { Name in } \\
\text { Voter list }\end{array}$ & $\begin{array}{c}\text { Number of } \\
\text { Women }\end{array}$ & $\begin{array}{c}\text { Percent } \\
(\%)\end{array}$ \\
\hline Yes & 255 & 72.9 \\
\hline No & 95 & 27.1 \\
\hline Total & $35^{\circ}$ & 100.0 \\
\hline
\end{tabular}

Available statistics shows that approximately 73 percent of the respondents had name in the voter list. However there were also some respondents $(27 \%)$, who reported that still their name is not in voter list. It was mainly because of citizenship and age factor and also lacking awareness among Madheshi women.

Table 2: Percent distribution of women who ever caste vote in the election

\begin{tabular}{|l|r|l|r|l|}
\hline \multirow{2}{*}{ Caste/Ethnicity } & \multicolumn{4}{|c|}{$\begin{array}{c}\text { Respondents who Ever } \\
\text { Caste Vote in the Election }\end{array}$} \\
\cline { 2 - 6 } & Yes & $\mathbf{( \% )}$ & \multicolumn{1}{l|}{ No } & $\mathbf{( \% )}$ \\
\hline Terai High Caste & $\mathbf{2 7}$ & 71.7 & $\mathbf{8}$ & $\mathbf{2 2 . 9}$ \\
\hline Terai Caste & 104 & 72.2 & 40 & $\mathbf{2 7 . 8}$ \\
\hline Terai Janjati & 54 & 74.0 & 19 & $\mathbf{2 6 . 0}$ \\
\hline Terai Dalit & 44 & 59.5 & 30 & 40.5 \\
\hline Muslim & $\mathbf{2 2}$ & 91.7 & $\mathbf{2}$ & 8.3 \\
\hline Total & $\mathbf{2 5 1}$ & 71.7 & 99 & $\mathbf{2 8 . 3}$ \\
\hline
\end{tabular}

Source: Status of Madheshi Women, Field Survey, 2011.

Among different caste/ethnic groups, 72.2 percent of the Tarai high caste women had ever cased vote in the election. The proportion of women who had ever caste the vote was found relatively low among Terai Dalits (59.5\%). The situation of Terai high caste was also seen poorer than other caste/ethnic groups in the experience of casting vote in the election.

Table 3: Women who casted vote by own conscience or guided by others

\begin{tabular}{|l|c|c|}
\hline Vote Casted & $\begin{array}{c}\text { Number of } \\
\text { Women }\end{array}$ & $\begin{array}{c}\text { Percent } \\
\text { (\%) }\end{array}$ \\
\hline Self Conscience & 197 & 58.1 \\
\hline Others' Guidance & 15 & 33.2 \\
\hline Pressure & 5 & 7.1 \\
\hline $\begin{array}{l}\text { Economic } \\
\text { enticement }\end{array}$ & 17 & 1.2 \\
\hline Other & 10 & 0.4 \\
\hline Total & $\mathbf{2 5 1}$ & $\mathbf{1 0 0 . 0}$ \\
\hline \multicolumn{2}{|c|}{ Source: Status of Madheshi Women, } \\
\multicolumn{2}{|r|}{ Field Survey, 2011. }
\end{tabular}

The respondents who had ever caste the vote were also asked that whether they caste vote by their own conscience or they were guided by others. Majority of them reported that they 
had casted vote by their own consciences (58\%). 33.2 percent of the respondents mentioned that they had given vote where their family members and the villagers suggested. 7.1 gave vote in the pressure and 1,2 percent got money to give vote.

Table 4: The cause of not casting vote

\begin{tabular}{|l|c|c|}
\hline $\begin{array}{l}\text { The Cause of not } \\
\text { Casting Vote }\end{array}$ & $\begin{array}{c}\text { Number } \\
\text { of Women }\end{array}$ & $\begin{array}{c}\text { Percent } \\
\text { (\%) }\end{array}$ \\
\hline $\begin{array}{l}\text { Name in not in } \\
\text { Voter list }\end{array}$ & 95 & 96.0 \\
\hline $\begin{array}{l}\text { Someone forged } \\
\text { on my name }\end{array}$ & 1 & 1.0 \\
\hline $\begin{array}{l}\text { Ignorance about the } \\
\text { importance of Vote }\end{array}$ & 3 & 3.0 \\
\hline Total & 99 & $\mathbf{1 0 0 . 0}$ \\
\hline
\end{tabular}

Source: Status of Madheshi Women, Field Survey, 2011

There were some respondents who reported that they have not get opportunity to give vote during election. Those women who had not caste vote in the election were asked the main causes of not casting vote. 96 percent of the respondents reported that their name was not in voter list. One percent said that some one else had given vote without their knowledge and 3 percent of them stated that they were not aware of their voting rights.

Table 5: Respondents know the name of ca member of their constituent

\begin{tabular}{|l|r|r|r|r|}
\hline \multirow{2}{*}{ Caste/ethnicity } & \multicolumn{5}{|c|}{$\begin{array}{c}\text { Respondents Know the } \\
\text { name of CA Member }\end{array}$} \\
\cline { 2 - 5 } & Yes & $\mathbf{( \% )}$ & \multicolumn{1}{|c|}{ No } & $\mathbf{( \% )}$ \\
\hline Terai High Caste & 11 & 3.1 & 24 & 6.9 \\
\hline Terai Caste & 51 & 14.6 & 88 & 24.1 \\
\hline Terai Janjati & 15 & 4.3 & 52 & 14.9 \\
\hline Terai Dalit & 11 & 3.1 & 61 & 17.4 \\
\hline Muslim & 5 & 1.4 & 19 & 5.4 \\
\hline Total & 93 & 26.6 & 257 & 73.4 \\
\hline
\end{tabular}

Source: Status of Madheshi Women,

Field Survey, 2011

It was very surprising that majority of women of all caste/ethnicity groups were not even familiar of their representative of Constituent Assembly. Among different caste/ethnic groups Terai caste was more familiar on their CA member than other caste/ethnic groups in this study area. Most of the Muslim women (1.4\%) and Terai high caste women (3.1\%) were unaware of this (see Table 5).

Table 6: Respondents know the name of ca member by literacy status

\begin{tabular}{|l|l|l|l|l|l|l|}
\hline \multirow{2}{*}{$\begin{array}{l}\text { Literacy } \\
\text { Status }\end{array}$} & \multicolumn{6}{|c|}{$\begin{array}{c}\text { Know the name of CA Member of } \\
\text { your Constituent Assembly }\end{array}$} \\
\cline { 2 - 7 } & Yes & $\mathbf{( \% )}$ & No & $\mathbf{( \% )}$ & Total & $\mathbf{( \% )}$ \\
\hline Literate & 36 & 35.6 & 65 & 64.4 & 101 & 100.0 \\
\hline Illiterate & 57 & $\mathbf{2 2 . 9}$ & 176 & 77.1 & 249 & 100.0 \\
\hline
\end{tabular}

Source: Status of Madheshi Women, Field Survey, 2011

The respondents were also asked whether they know the name of CA member of their constituent to know their awareness level and awareness among Madheshi women on the name of their Constituent Assembly Member shows that only 27 percent of the respondents who knew the name of their CA member And among them 35.6 percent of the literate women were found that they were familiar with the name of their CA member of their constituency. A large proportion of literate women were unaware of their CA member's name. Among illiterate women it was worst condition. Data shows that only 23 percent of the illiterate women were aware on their name of CA member.

\section{Conclusion}

Women's political awareness as well as their participation as a voters or as a candidate of representative of any political party, is crucial to the functioning of inclusive democracy. Literacy status also shows that such types of political awareness were high among literate women than illiterate women of the respective caste/ethnic groups. It is also seen that awareness of political activities were found better among Terai caste and in second Terai Janjati caste The situation of awareness found that the Terai high caste and Terai Dalits was 
similar. But awareness level was very low among Muslim women.

As said by Dr. Harka Gurung in his article on Trident and Thunderbold; Culture Dynamics in Nepalese Politics, "Basically, there are three main social groups in Nepal that have bee marginalized by the state's monopolistic policy. They are Janjati (ethnic groups) on the basis of culture, the Dalits (untouchables) on the basis of caste, and the Madheshi (Tarai) on the basis of geography" SIRF (2007).

In Parsa district study has shown that women's political participation is restricted by many families and societies. Women have no autonomy to take their own decisions to whom they give vote or in which political party they participate.

It is about time that it should be realize that investment in women is the single most important path to higher productivity for society as a whole. Experience shows that women oriented development projects have been resulted in terms of social benefits. Thus study shows that Madheshi women are still known to be more socially, politically and economically oppressed than women in the other parts of the country. It may be because of conservative social set up and strong social taboos. However the democratization of ruling system from couple of decade's claims to provide equal opportunity to the people including the gender from all over the country but the structure of the political parties is still exclusionary against marginalized community like Madheshi women and favors the traditional ruling community.

\section{Recommendation}

Participation of all citizens is necessary for nation building and Madheshi women are also important part of the nation. People can enjoy their rights only if the nation is strong. For this mission to be successful, participation of all people in leadership is one of the important prerequisites.
In order to change the status of Madheshi women in Nepal, a healthy political atmosphere should be created. Gender discrimination should be minimized. No doubt it will take time but continuous efforts and initiatives will bring a positive change. They should not be provided with only one day democracy to cast their vote.

The role of women representatives should be in promoting female participation in political arena. They should mobilise (local Madheshi women), bring them forward and motivate them to stand for higher positions. Women education is precondition for the application of all women rights. Women Organizations should be trained in Terai region and advocacy to press for quotas should be initiated and thus obtain more decision making positions for women. More women in decision making process help to create an egalitarian society, thus creating environment for a vibrant democracy.

All Nepal's Women's Organization, Government Organizations, NGOs, INGOs, Civil societies have played a vital role to bring to the light exploitation, injustice, unequal and discriminatory treatment but the problem they face will not be over. The political revolution now needs to be accompanied by drastic social reform on the ground. Therefore, gender mainstreaming in the development activities including inclusive participation in governance system in Nepal, is must to empower women of all sectors of society.

\section{References}

Barbara Nelson and Nafima Chaudhary, (1994). Women and Politics World Wide. New Heaven: Yale University Press

Chaudhary, Dipak, (2008). Nepalko Madheshi Samaj. Kathmandu: Ratna Pustak Bhandar, Nepal.

Acharya, M. (1980). The Status of Women in Nepal, Vol.1: Background Report. Part 1. Statistical 
Profile of Nepalese Women: A Critical Review. Kathmandu: Centre for Economic Development Administration (CEDA).

Gurung, H. (2007). From Exclusion To Inclusion: Socio-political Agenda for Nepal. Lalitpur: Social Inclusion Research Fund (SIRF).

Haan, de Arjan, (1998). Social Exclusion: An Alternative Concept of the Study of Deprivation, IDS Bulletin Vol.29 no.1, pp 10-19.

HURDAC, (2009). A Journal on Madhesh Issue, HURDAC, PP:36

Nepal Human Development Report, (2009). United Nations Development Programme (UNDP), Kathmandu: UNDP.
Nepal Labour Force Survey, (2008). ILO, UNDP, Kathmandu: CBS.

Shrestha, I. \& Hachhethu, K. (2005). "Women and Governance : Democratic Processes in South Asia-Nepal Chapter" in "A Journal of Women's Studies".pp 25-27.

SIRF, (2007). From Exclusion to Inclusion: SocioPolitical Agenda for Nepal. Lalitpur: Social Inclusion Research Fund (SIRF).

United Nations (1995). World Summit for Social Development (Copenhagen: UN). Retrieved from http://www.un.org/esa/socdev/wssd. Accessed on June 20,2008. 